\title{
Childhood Acute Lymphoblastic Leukemia with Near-Tetraplody And t(12; 21) (p13;q22) Translocation: A Case Report
}

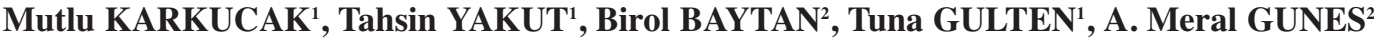 \\ ${ }^{1}$ Uludag University Faculty of Medicine, Department of Medical Genetics, Bursa, TURKEY \\ ${ }^{2}$ Uludag University Faculty of Medicine, Department of Pediatric Hematology, Bursa, TURKEY
}

\begin{abstract}
Fluroscent in situ hybridization analysis indicated presence of $\mathrm{t}(12 ; 21)(\mathrm{p} 13 ; \mathrm{q} 22)$ translocation and near-tetraploidy in a case who 11-year-old boy and diagnosed with B precursor acute lymphoblastic leukemia (ALL). Although, some studies suggest good prognostic effect of translocation $\mathrm{t}(12 ; 21)$ ( $\mathrm{p} 13 ; \mathrm{q} 22)$, there were very little data regarding the prognostic effect of $\mathrm{Ne}$ ar-tetraploidy. Here we discussed the prognostic relevance of both $t(12 ; 21)(p 13 ; q 22)$ translocation and near tetraplody in Pre-B ALL.
\end{abstract}

Keywords: Childhood acute lymphoblastic leukemia, Near-Tetraploidy , t(12;21)

\section{ÖZET}

t(12;21)(p13;q22) translokasyonu ve Near Tetraplodi Bulunan Çocukluk Çağı Akut Lenfoblastik Lösemili Bir Olgu Sunumu

Pre- B Akut Lenfoblastik Lösemi tanısı konulan 11 yaşında erkek olguda, Floresans insitu hibridizasyon analizinde $\mathrm{t}(12 ; 21)(p 13 ; q 22)$ translokasyonu ve near-tetraploidi beraber olduğu gösterilmiştir. Bazı çallşmalarda t(12;21)(p13;q22) translokasyonunun iyi prognostik etki oluşturduğu belirtmelerine rağmen near-tetraploidinin prognostik etkisi hakkında çok az bilgi vardır. Burada Pre-B Akut Lenfoblastik Lösemili olguda t(12;21)(p13;q22) translokasyonu ile birlikte near tetraplodi bulgularının birlikte etkisi tartışımaktadır.

Anahtar Kelimeler: Çocukluk çağı akut lenfoblastik lösemi, Near-Tetraplodi, t(12;21) 


\section{INTRODUCTION}

Acute lymphoblastic leukemia (ALL) is the most frequently observed malign tumors in childhood, which covers about $1 / 3$ of all malign tumors observed in childhood. It is most frequently observed between the ages of 2-5.' In childhood leukemia, structural variations associated with bad prognosis like $\mathrm{t}(9 ; 22)$ (q34;q11), $\mathrm{t}(1 ; 19)$ (q23;p13), $\mathrm{t}(11 \mathrm{q} 23)$ translocations and good prognosis like $\mathrm{t}(12 ; 21)$ (p13;q22) translocations are observed. Decreases and increases in the replication of total chromosome number are also frequently detected. Hyperdiploidy characterized by increase in the number of chromosomes $(>46)$ is a genetic variation that is observed frequently in childhood and while the frequency is about $30 \%$, hypodiploidy characterized by a decrease in chromosome number $(<46)$ is identified at a rate of about $5 \% .{ }^{2,3}$ While hypodiploidy is associated with poor prognosis, hyperdiploidy and especially high level of hyperdiploidy (number of chromosomes being about 50-67) are associated with good prognosis.

Right along with hyperdiploidy, near-triploidy (number of chromosomes between 68-80), is observed less frequently than near-tetraploidy (number of chromosomes $>80$ ) and more information is needed on prognostic importance of these cases. Prognostic assessment varies depending on subgroups of hyperdiploidy and hypodiploidy as well as the types of chromosomes they contain.

The present case is a Near-Tetraplody associated with $\mathrm{t}(12 ; 21)(\mathrm{p} 13 ; \mathrm{q} 22)$ translocation. The prognostic value of this variation was discussed in the light of the literature.

\section{CASE REPORT}

An 11-year-old boy was admitted to our department of pediatric Hematology, in October 2006 with the complaint of pain in right leg and right chest. Physical examination was normal. Hematological Complete blood count revealed a hemoglobin value of $2.8 \mathrm{~g} / \mathrm{dl}$. Thrombocytes were $14100 / \mathrm{mm} 3$, leukocytes were $6600 / \mathrm{mm} 3$, with $69 \%$ blasts, $25 \%$ lymphocytes, $3 \%$ polymorph nuclear leucocytes. Bone marrow analysis showed $100 \%$ ALL type I blasts. The patient was administered chemotherapy with the diagnosis of ALL. Before chemotherapy, the bone marrow of the patient was analyzed, using cytogenetic analysis with Interphase-FISH method and translocations of $\mathrm{t}(9 ; 22)(\mathrm{q} 34 ; \mathrm{q} 11)$, $\mathrm{t}(12 ; 21)(\mathrm{p} 13 ; \mathrm{q} 22)$ and 11q23 (MLL fusion gene) were detected in the patient. No reproduction was observed in the culture prepared for the cytogenetic analysis of bone marrow. On the other hand, $\mathrm{t}(12 ; 21)(\mathrm{p} 13 ; \mathrm{q} 22)$ translocation was detected with FISH analysis, and 4-6 copies of 12th and 21st chromosomes were present. Three to six copies of other chromosomes were present and the patient was accepted as a near-tetratploidy case with $t(12 ; 21)(p 13 ; q 22)$ translocation. On the 8th day of treatment there were $30-40 \%$ of blasts in bone marrow analysis that led us to consider that the response to treatment was rather slow. The patient was started high risk group chemotherapy. Molecularcytogenetic analysis was conducted after remission. No $\mathrm{t}(12 ; 21)(\mathrm{p} 13 ; \mathrm{q} 22)$ translocation was detected and the chromosomes were now dizomic. Thus, it was concluded that full cytogenetic response was achieved with the treatment (Figure 1). The patient who was being followed-up for the last 4 years has relapsed in 2010.

\section{DISCUSSION}

Cytogenetic analysis is a new tool in monitoring the childhood leukemia before and after treatment. Cytogenetic analysis is one of the most traditional and important methods used in determining chromosomal anomalies. Failure rates are observed 20$40 \%$ depending on the culture, while these figures vary between laboratories. On the other hand, rates of catching the actual anomaly decreases because of quality problems in metaphase nuclei and because of low mitotic index. ${ }^{4}$

As a result of the peripheral smear analysis and clinical evaluations conducted for our case the patient was classified in a high risk group and his treatment was organized according to ALL-BFM-95 HRG protocol. Molecular cytogenetic (FISH) evaluation showed near-tetraploidy and $\mathrm{t}(12 ; 21)(\mathrm{p} 13 ; \mathrm{q} 22)$ translocation and translocations of $\mathrm{t}(9 ; 22)(\mathrm{q} 34 ; \mathrm{q} 11), \mathrm{t}(12 ; 21)(\mathrm{p} 13 ; \mathrm{q} 22)$ and 11q23 (MLL fusion gene) before treatment. After therapy, cells with diploidy (two copies) and $t(12 ; 21)(p 13 ; q 22)$ translocation were not observed in the FISH analysis. 


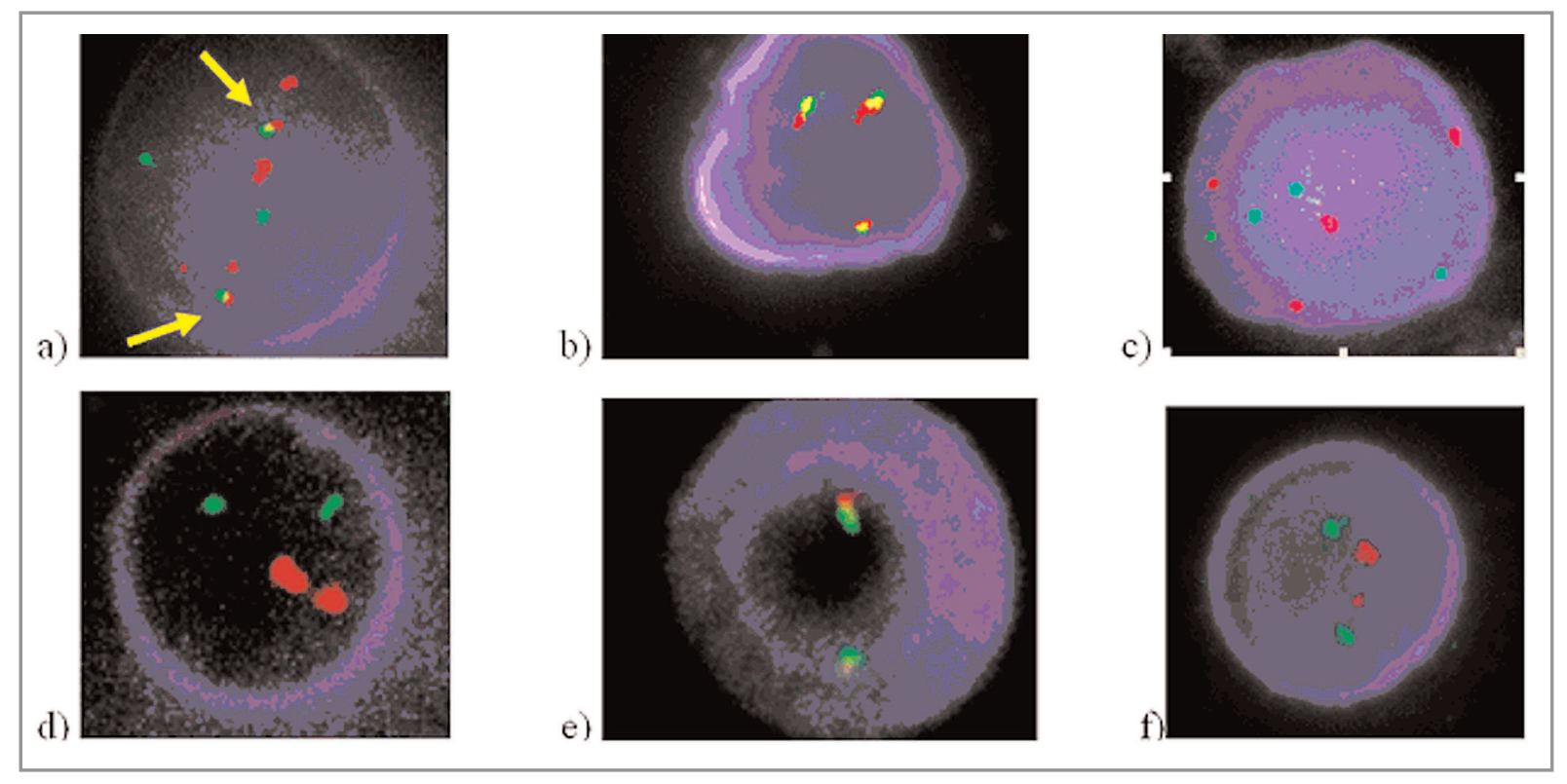

Figure 1. FISH analysis before and after treatment a) before treatment $t(12 ; 21)$ translocation (arrows) with increased copies of chromosomes 12 and 21 b) before treatment absence of $\mathrm{t}(11 \mathrm{q} 23)$ translocation with increased copies of chromosome 11 c) before treatment absence of $\mathrm{t}(9 ; 22)(\mathrm{q} 34 ; \mathrm{q} 11)$ translocation with increased copies of chromosomes 9 and 22 d) after treatment absence of $\mathrm{t}(12 ; 21)$ translocation with double copies of chromosomes 12 and 21 e) after treatment absence of $\mathrm{t}(11 \mathrm{q} 23)$ translocation with double copies of chromosome $11 \mathrm{f})$ after treatment absence of $\mathrm{t}(9 ; 22)(q 34 ; q 11)$ translocation with double copies of chromosomes 9 and 22.

While in general $\mathrm{t}(12 ; 21)(\mathrm{p} 13 ; \mathrm{q} 22)$ translocation is considered a good prognostic factor in childhood ALL's $^{5-7}$, several investigators reported a higher probability of relapse development..$^{89}$ In a study conducted by the Pediatric Oncology Group (POG) and St. Jude Children's Research Hospital (St. Jude) groups, among 1791 patients with childhood ALL, 6 were $(0.3 \%)$ near-triploidy and 20 were (1.1\%) near-tetraploidy. ${ }^{10}$ In another study, cytogenetic anomaly was studied among 169 childhood ALL with $\mathrm{t}(12 ; 21)(\mathrm{p} 13 ; \mathrm{q} 22)$ translocation and it was shown that near-triploidy existed in a single $(0.6 \%)$ case and near-tetraploidy existed in 10 $(5.9 \%)$ patients. ${ }^{11}$ Very little information is available in the literature on the prognostic outcome of these anomalies. In a study conducted by Attarbaschi et al. near-tetraploidy was detected in 12 of 783 patients $(1.5 \%)$ and among these 9 were pre-B ALL type and 3 were T-ALL type patients. Among neartetraploidy patients $\mathrm{t}(12 ; 21)(\mathrm{p} 13 ; \mathrm{q} 22)$ translocation was detected in 8 of 9 patients with Pre-B ALL, while there was no translocation in patients with TALL. These were followed up for an average period of 11.4 years no relapses or deaths were obser- ved. The fact that the outcome with near-tetraploidy patients is excellent, this can probably be explained by the characteristics of the existence of pre-B ALL type and $\mathrm{t}(12 ; 21)(\mathrm{p} 13 ; \mathrm{q} 22)$ translocation. ${ }^{12}$

Considering the chromosomes analysed before treatment, in our case that has near tetroploidy and TEL-AML1 translocation clone, having the person relapsed in the fourth year while there was TELAML1 translocation associated to good prognosis having full cytogenic response to chemotherapy treatment will contribute to the literature, in terms of prognostic follow up of this type of cases.

\section{REFERENCES}

1. Ma SK, Wan TS, Chan LC. Cytogenetics and molecular genetics of childhood leukemia. Hematol Oncol 17: 91-105, 1999.

2. Zemanova Z, Michalova K, Sindelarova L, et al. Prognostic value of structural chromosomal rearrangements and small cell clones with high hyperdiploidy in children with acute lymphoblastic leukemia. Leukemia Research 29: 273-281, 2005. 
3. Heerema NA, Nachman JB, Sather HN, et al. Hypodiploidy with less than 45 chromosomes confers adverse risk in childhood acute lymphoblastic leukemia: a report from the children's cancer group. Blood 94: 4036-4045, 1999.

4. Moorman AV, Clark R, Farrell M, et al.Probes for hidden hyperdiploidy in acute lymphoblastic leukemia. Genes Chromosomes Cancer 16:40-45, 1996.

5. Pui $\mathrm{CH}$. Childhood leukemias. N Engl J Med 332:1618-1630, 1995.

6. Rubnitz JE, Downing JR, Pui CH, et al. TEL gene rearrangement in acute lymphoblastic leukemia: a new genetic marker with prognostic significance. J Clin Oncol 15: 1150-1157, 1997.

7. Rubnitz JE, Look AT. Molecular genetics of childhood leukemias. J Pediatr Hematol Oncol 20 :1-11, 1998.

8. Seeger K, Adams HP, Buchwald D, et al. TELAML1fusion transcript in relapsed childhood acute lymphoblastic leukemia. The Berlin-Frankfurt-Munster Study Group. Blood 91: 1716-1722, 1998.

9. Rubnitz JE, Behm FG, Wichlan D, et al. Low frequency of TEL-AML1 in relapsed acute lymphoblastic leukemia supports a favorable prognosis for this genetic subgroup. Leukemia.13: 19-21,1999.

10. Pui $\mathrm{CH}$, Carroll AJ, Head D, et al. Near-triploid and near-tetraploid acute lymphoblastic leukemia of childhood. Blood 76: 590-596, 1990.
11. Raynaud SD, Dastugue N, Zoccola D, et al. Cytogenetic abnormalities associated with the $t(12 ; 21)$ : a collaborative study of 169 children with $t(12 ; 21)$-positive acute lymphoblastic leukemia. Leukemia 13: 13251330, 1999.

12. Attarbaschi A, Mann G, König M, et al. Near-tetraploidy in childhood B-cell precursor acute lymphoblastic leukemia is a highly specific feature of ETV6/RUNX1-positive leukemic cases. Genes Chromosomes Cancer 45: 608-611,2006

\section{Correspondence}

Dr. Tahsin YAKUT

Uludağ Üniversitesi Tıp Fakültesi

Tıbbi Genetik Anabilim Dalı

16059 Bursa / TURKEY

Tel: (+90.224) 2954371

e-mail: tyakut@uludag.edu.tr 